\title{
Sponge biodiversity
}

\author{
R.W.M. van Soest \\ Zoological Museum of the University of Amsterdam, PO Box 94766, 1090 GT Amsterdam, The Netherlands. \\ E-mail: soest@science.uva.nl
}

\author{
The answer's fairly simple: Sponges feed like Protozoa, \\ And haven't any enteron like other Metazoa; \\ Their 'gastral cells' are clusters of primaeval Collared Monads, \\ And their bodies have no traces of muscles, nerves or gonads. \\ Even their eggs are products of choanocyte divisions, \\ And therefore carry with them Choanoflagellate traditions: \\ Flagellate or Amoeboid, with collars or without, \\ They still are Collared Monads — though certainly more stout.
}

from The Amphiblastula and the origin of sponges Walter Garstang, Larval Forms.

Walter Garstang (1868-1949) was a pioneer in pure marine biology and was on the staff of the Marine Biological Association, Plymouth from the day it opened in 1888 until 1902.

Sponges are an integral part of marine benthic communities with a high-impact role in benthic-pelagic coupling processes, as an important source of food for demersal grazers and predators, as hosts of a highly diverse microbial biomass, and as bio-eroders. Sponges provide age-old (hygienic) services to humans and continue to be of interest in modern times as sources of an unprecedented array of useful substances.

Recently, we observe an enhanced scientific effort in the field of marine biodiversity research, spurred on by a growing awareness of the vulnerability of nature's biodiversity and an urgent need to have it inventoried and monitored. In the case of sponges, there is an unmistakable additional inducement from the increased availability of proper tools for such biodiversity research. The taxonomic knowledge base has been summarized and rationalized in a single comprehensive 'bible', the Systema Porifera, a multi-author, 2002 effort edited by Hooper \& van Soest, allowing for the first time unambiguous identification of observed sponges to properly revised and peer-reviewed genera, families and orders. There is now a searchable online database listing all the described sponge taxa and their origin (http://www.marinespecies.org/porifera/). Several additional databases are available either on-line or on CDROM listing the natural products and microbial symbionts found in sponges ('MarinLit', Blunt \& Munro, 2006; http://hbmmd.hboi.edu/index.htm) stimulating research into the microbiota and the chemistry of sponges. The molecular tools for classifying sponge species and higher taxa are becoming generally available, primers are being developed for routine sequencing of large numbers of taxa and genes, and an on-line sponge barcode database is now operational (http://www. spongebarcoding.org). The results of all these improvements are that sponge researchers, roaming the sea bottom in all regions and depths of the world's oceans, are now able to efficiently inventory the sponge faunas, and describe and classify species and higher taxa phylogenetically and ecologically. There is also a heightened effort in 'applied' sponge research, exploring the societal use of sponges.

It is proper and fitting that the Marine Biological Association of the United Kingdom comes forward with a special volume in its Journal covering these various sponge efforts. Right from the start of the Association, way back in 1884, and up to the present, the Journal has published sponge papers on a regular basis. Sponge fisheries and sponge culture were subjects addressed repeatedly in the earlier volumes of the Journal by E. Allen, the first secretary of the Association (1896), G.P. Bidder (1896, 1902) and L.R. Crawshay (1915, 1939). Sponge epigones such as A. Dendy and M. Burton discussed taxonomy, faunistics and ecology in the Journal and contributed to the authorative Plymouth Marine Fauna (e.g. Burton, 1957). Continuing along these lines, the volume presented here unites a series of 43 articles covering a wide range of sponge biodiversity studies, without pretending to delimit past or future eras of sponge research. As such it provides an overview of current sponge biodiversity research at this moment in time, and with 21 nationalities involved demonstrates the strongly international nature of sponge diversity science. 
Alpha systematics, i.e. describing and revising the status of the species of sponges extant in this world, continues to be a very necessary effort. Our current understanding of sponge species diversity is that approximately 8500 valid species have been described (among more than 10,000 described species overall), whereas at least double the number is likely to be extant, given the fact that, for example, Asian tropical, South American temperate and global deep-sea habitats remain to a large extent unexplored. For that reason, we are fortunate to present several articles from these habitats (Azzini et al.; Calcinai et al.; Carballo et al.; Esteves et al.; Ereskovsky; Moraes \& Muricy; Plotkin \& Janussen; Rützler et al.; Tabachnick \& Menshenina; Urteaga \& Pastorino). Surprisingly, regions and habitats of which we were confident to have profound knowledge of the extant species such as the north-east Atlantic or Antarctica, appeared in inventories of local faunas to yield several species new to science and several cases of confused taxonomy (Kefalas \& Castritsi-Catharios; Picton \& Goodwin; Schoenberg \& Beuck; Rios \& Cristobo; Cardenas et al.; Vacelet et al.). Whereas taxonomy as a science appears to be in decline globally, we may consider ourselves lucky to see an upsurge in alpha taxonomy of sponges from younger scientists.

The Systema Porifera with its predominantly morphological classification forms the perfect basis for testing phylogenetic relationships of sponge groups at all hierarchical levels. Can the orders, families and genera recognized and defined in it be retrieved as monophyletic groups using gene sequences? Previous overviews (Hooper \& van Soest, 2004; Boury-Esnault, 2006) of the discrepancies and problematic relationships in the major group of Demospongiae already indicated that serious mismatches are apparent. Studies presented here (Erpenbeck et al. b; Erpenbeck et al. c; Raleigh et al.; Kober \& Nichols) continue to indicate that at all hierarchical levels several operational morphological markers are not supported by molecular markers, despite occasional congruence. That some of the blame for the mismatch could fall to the molecular side is demonstrated by studies of Alvarez et al. and Erpenbeck et al. a. Still, studies presented here (Cardenas; Heim et al.) show that a combined approach of morphology and molecules is often successful and may be the future of sponge classification. In the meantime, development of a well-functioning DNA taxonomy is within reach, as is discussed in the review of Wörheide \& Erpenbeck in this volume. This may be particularly important for the many groups of sponges with poor morphological characters.

If we know our species from reliable sources, then regional or local sponge inventories are a highly necessary follow up, as we need to document geographical distributions, spatial turnover and quantitative presence to be able to identify keystone species and subjects for monitoring and experimental work. The inventories may be used for biogeographical analysis, community ecology and biodiversity informatics, and ultimately for conservation purposes. The overall message from such studies is that sponge species morphology and distribution follow predictable biological and environmental patterns. Community patterns (morphological, spatial, temporal, geographical) are detectable from accumulated individual species distributions only by multivariate statistics and rigorous measurements of environmental variables.

We present simple inventories of previously unexplored regions and habitats (Lanna et al.; Putchakarn; Picton \& Goodwin; Xavier \& van Soest) as well as reviews of wellstudied areas in which correlations with environmental and biotic factors are determined using state-of-the-art ecological statistics (Bell; Cleary \& de Voogd).

We also include several experimental and observational studies on keystone species (Cavalcanti et al.; Schläppy et al.; Watling; Wulff) and studies on microsymbiont composition (Erwin \& Thacker) and transmission from parent to offspring (de Caralt et al.; Maldonado).

Increased monitoring of sponge distributions reveals that in sponges as in several other marine groups the phenomenon of invasive species is now observable in several regions of Europe (van Soest et al.; Longo et al.). We can only speculate on the impact such species may have on the local fauna.

Finally the role that sponges play in society is highlighted in several exemplary studies on the knowledge of sponges in Ancient Greece (Voutltsiadou), the physical properties of sponge fibres (Castritsi-Catharios et al.), the ancient use of beach-worn sponges in the Faroes (Svanberg) and modern approaches to make use of sponge products (de Voogd; Sokolover \& Ilan).

Rob van Soest

Zoological Museum of the University of Amsterdam.

\section{REFERENCES}

Alvarez, B., Krishnan, M. \& Gibb, K., 2007. Analysis of intragenomic variation of the rDNA internal transcribed spacers (ITS) in Halichondrida (Porifera: Demospongiae). Fournal of the Marine Biological Association of the United Kingdom, 87, 1599-1605.

Azzini, F., Calcinai, B. \& Pansini, M., 2007 A new species of Coelocarteria (Porifera: Demospongiae) from Sulawesi, Indonesia. Fournal of the Marine Biological Association of the United Kingdom, 87, 1349-1353.

Bell, J.J., 2007. The ecology of sponges in Lough Hyne Marine Nature Reserve (south-west Ireland): past, present and future perspectives. Fournal of the Marine Biological Association of the United Kingdom, 87, 1655-1668.

Blunt, J.W. \& Munro, M.H.G., 2006. MarinLit. A database of the literature on marine natural products for use on a Macintosh computer prepared and maintained by the Marine Chemistry Group, Department of Chemistry, University of Canterbury, New Zealand. CD-ROM version.

Boury-Esnault, N., 2006. Systematics and evolution of Demospongiae. Canadian Fournal of Zoology, 84, 205-224.

Calcinai, B., Cerrano, G. \& Bavestrello, G., 2007. Three new species and one re-description of Aka. Fournal of the Marine Biological Association of the United Kingdom, 87, 1355-1365.

Caralt, S. de, Uriz, M.J. \& Wijffels, R.H., 2007. Vertical transmission and successive location of symbiotic bacteria during embryo development and larva formation in Corticium candelabrum (Porifera: Demospongiae). Fournal of the Marine Biological Association of the United Kingdom, 87, 1693-1699.

Carballo, J.L., Hepburn, L., Nava, H.H., Cruz-Barraza, J.A. \& Bautista-Guerrero, E., 2007. Coral boring Aka-species (Porifera: Phloeodictyidae) from Mexico with description of Aka cryptica sp. nov. Journal of the Marine Biological Association of the United Kingdom, 87, 1477-1484. 
Cárdenas, P., Xavier, J., Tendal, O.S., Schander, C. \& Rapp, H.T., 2007. Redescription and resurrection of Pachymatisma normani (Demospongiae: Geodiidae), with remarks on the genus Pachymatisma. Fournal of the Marine Biological Association of the United Kingdom, 87, 1511-1525.

Castritsi-Catharios, J., Magli, M. \& Vacelet, J., 2007. Evaluation of the quality of two commercial sponges by tensile strength measurement. Fournal of the Marine Biological Association of the United Kingdom, 87, 1765-1771.

Cavalcanti, F.F., Zilberberg, C. \& Klautau, M., 2007. Seasonal variation of morphological characters of Chondrilla aff. nucula (Porifera: Demospongiae) from the south-east coast of Brazil. Fournal of the Marine Biological Association of the United Kingdom, 87, $1727-1732$

Cleary, D.F.R. \& Voogd, N.J. de, 2007. Environmental associations of sponges in the Spermonde Archipelago, Indonesia. Fournal of the Marine Biological Association of the United Kingdom, 87, 16691676.

Ereskovsky, A.V. \& Willenz, P., 2007. Esperiopsis koltuni sp. nov. (Demospongiae: Poecilosclerida: Esperiopsidae), a carnivorous sponge from deep water of the Sea of Okhotsk (North Pacific). Fournal of the Marine Biological Association of the United Kingdom, 87, 1379-1386.

Erpenbeck, D., Cleary, D.F.R., Voigt, O., Nichols, S.A., Degnan B.M., Hooper, J.N.A. \& Wörheide, G., 2007a. Analysis of evolutionary, biogeographical and taxonomic patterns of nucleotide composition in demosponge rRNA. Fournal of the Marine Biological Association of the United Kingdom, 87, 1607-1614.

Erpenbeck, D., Duran, S., Rützler, K., Paul, V., Hooper, J.N.A. \& Wörheide, G., 2007b. Towards a DNA taxonomy of Caribbean demosponges: a gene tree reconstructed from partial mitochondrial $\mathrm{CO} 1$ gene sequences supports previous rDNA phylogenies and provides a new perspective on the systematics of Demospongiae. Fournal of the Marine Biological Association of the United Kingdom, 87, 1563-1570.

Erpenbeck, D., List-Armitage, S., Alvarez, B., Degnan, B.M., Wörheide, G. \& Hooper, J.N.A., 2007c. The systematics of Raspailiidae (Demospongiae: Poecilosclerida: Microcionina) reanalysed with a ribosomal marker. Journal of the Marine Biological Association of the United Kingdom, 87, 1571-1576.

Erwin, P.M. \& Thacker, R.W., 2007. Incidence and identity of photosynthetic symbionts in Caribbean coral reef sponge assemblages. Fournal of the Marine Biological Association of the United Kingdom, 87, 1683-1692.

Esteves, E.L., Lôbo-Hajdu, G. \& Hajdu, E., 2007. Three new species of Crambe (Crambeidae: Poecilosclerida: Demospongiae) from the south-eastern Pacific, with a review of morphological characters for the genus. Fournal of the Marine Biological Association of the United Kingdom, 87, 1367-1378.

Garstang, W., 1985. Larval forms and other zoological verses. Chicago \& London: University of Chicago Press.

Heim, I., Nickel, M. \& Brümmer, F., 2007. Phylogeny of the genus Tethya (Tethyidae: Hadromerida: Porifera): molecular and morphological aspects. Fournal of the Marine Biological Association of the United Kingdom, 87, 1615-1627.

Hooper, J.N.A. \& Soest, R.W.M. van, 2004. Systema Porifera. A guide to the classification of sponges .... the end of a beginning. Bolletino dei Musei e degli Istituti Biologici dell'Universitá di Genova, 68 , 19-38.

Kefalas, E. \& Castritsi-Catharios, J., 2007. Taxonomy of some sponges (Porifera: Demospongiae) collected from the Aegean Sea and description of a new species. Fournal of the Marine Biological Association of the United Kingdom, 87, 1527-1538.

Kober, K.M. \& Nichols, S.A., 2007. On the phylogenetic relationships of hadromerid and poecilosclerid sponges. Fournal of the Marine Biological Association of the United Kingdom, 87, 15851598.
Lanna, E., Rossi, A.L., Cavalcanti, F.F., Hajdu, E. \& Klautau, M., 2007. Calcareous sponges from São Paulo State, Brazil (Porifera: Calcarea: Calcinea) with the description of two new species. Fournal of the Marine Biological Association of the United Kingdom, 87, 1553-1561.

Longo, G., Mastrototaro, F. \& Corriero, G., 2007. Occurrence of Paraleucilla magna (Porifera: Calcarea) in the Mediterranean Sea. Fournal of the Marine Biological Association of the United Kingdom, 87, 1749-1755.

Maldonado, M., 2007. Intergenerational transmission of symbiotic bacteria in oviparous and viviparous demosponges, with emphasis on intracytoplasmically-compartmented bacterial types. Fournal of the Marine Biological Association of the United Kingdom, 87, 1701-1713.

Moraes, F. \& Muricy, G., 2007. A new species of Stoeba (Demospongiae: Astrophorida) from oceanic islands off northeastern Brazil. Fournal of the Marine Biological Association of the United Kingdom, 87, 1387-1393.

Picton, B.E. \& Goodwin, C.E., 2007. Sponge biodiversity of Rathlin Island, Northern Ireland. Fournal of the Marine Biological Association of the United Kingdom, 87, 1441-1458.

Plotkin, A.S. \& \& Janussen, D., 2007. New genus and species of Polymastiidae (Demospongiae: Hadromerida) from the Antarctic deep sea. Fournal of the Marine Biological Association of the United Kingdom, 87, 1395-1401.

Putchakarn, S., 2007. Species diversity of marine sponges dwelling in coral reefs in Had Khanom-Mo Ko Thale Tai National Park, Nakhon Si Thammarat Province, Thailand. Fournal of the Marine Biological Association of the United Kingdom, 87, 1635-1642.

Raleigh,J., Redmond, N.E., Delahan, E., Torpey, S., Soest, R.W.M. van, Kelly, M. \& McCormack, G.P., 2007. Mitochondrial Cytochrome oxidase 1 phylogeny supports alternative taxonomic scheme for the marine Haplosclerida. Fournal of the Marine Biological Association of the United Kingdom, 87, 1577-1584.

Rios, P. \& Cristobo, J., 2007. A new species of Phorbas (Porifera: Poecilosclerida) from the Bellingshausen Sea, Antarctica. Fournal of the Marine Biological Association of the United Kingdom, 87, 1485-1490.

Rützler, K., Piantoni, G. \& Díaz, M.G., 2007. Lissodendoryx: rediscovered type and new tropical western Atlantic species (Porifera: Demospongiae: Poecilosclerida: Coelosphaeridae). Fournal of the Marine Biological Association of the United Kingdom, 87, 1491-1510.

Schläppy, M.-L., Hoffmann, F., Røy, H., Wijffels, R.H., Mendola, D., Sidri, M. \& Beer, D. de, 2007. Oxygen dynamics and flow patterns of Dysidea avara (Porifera: Demospongiae). Fournal of the Marine Biological Association of the United Kingdom, 87, 1677-1682.

Schönberg, C.H.L. \& Beuck, L., 2007. Where Topsent went wrong: Aka infesta a.k.a. Aka labyrinthica (Demospongiae: Phloeodictyidae) and implications for other Aka species. Fournal of the Marine Biological Association of the United Kingdom, 87, 1459-1476.

Soest, R.W.M. van, Kluijver, M.J. de, Bragt, P.H. van, Faasse, M., Nijland, R., Beglinger, E.J., Weerdt, W.H. de \& Voogd, N.J. de, 2007. Sponge invaders in Dutch coastal waters. Fournal of the Marine Biological Association of the United Kingdom, 87, 1733-1748.

Sokolover, N. \& Ilan, M., 2007. Assessing anti-predatory chemical defences among ten eastern Mediterranean sponges. Fournal of the Marine Biological Association of the United Kingdom, 87, 1785-1790.

Svanberg, I., 2007. Human usage of mermaid's glove sponge (Isodictya palmata) on the Faroes. Fournal of the Marine Biological Association of the United Kingdom, 87, 1773-1775.

Tabachnick, K.R. \& Menshenina, L.L., 2007. Revision of the genus Asconema (Porifera: Hexactinellida: Rossellidae). Fournal of the Marine Biological Association of the United Kingdom, 87, 1403-1429.

Urteaga, D. \& Pastorino, G., 2007. Pione angelae sp. nov. (Porifera: Hadromerida: Clionaidae) a new species of boring sponge inhabiting pagurized shells from the south-western Atlantic. Fournal of the Marine Biological Association of the United Kingdom, 87, 1431-1439. 
Vacelet, J., Bitar, G., Carteron, S., Zibrowius, H. \& Perez, T., 2007. Five new sponge species (Porifera: Demospongiae) of subtropical or tropical affinities from the coast of Lebanon (eastern Mediterranean). Fournal of the Marine Biological Association of the United Kingdom, 87, 1539-1552.

Voogd, N.J. de, 2007. An assessment of sponge mariculture potential in the Spermonde Archipelago, Indonesia. Journal of the Marine Biological Association of the United Kingdom, 87, 1777-1784.

Voultsiadou, E., 2007. Sponges: an historical survey of their knowledge in Greek antiquity. Fournal of the Marine Biological Association of the United Kingdom, 87, 1757-1763.

Watling, L., 2007. Predation on copepods by an Alaskan cladorhizid sponge. Fournal of the Marine Biological Association of the United Kingdom, 87, 1721-1726.
Wörheide, G. \& Erpenbeck, D., 2007. DNA taxonomy of spongesprogress and perspectives. Fournal of the Marine Biological Association of the United Kingdom, 87, 1629-1633.

Wulff, J.L., 2007. Disease prevalence and population density over time in three common Caribbean coral reef sponge species. Fournal of the Marine Biological Association of the United Kingdom, 87, $1715-1720$.

Xavier, J. \& Soest, R.W.M. van, 2007. Demosponge fauna of Ormonde and Gettysburg Seamounts (Gorringe Bank, northeast Atlantic): diversity and zoogeographical affinities. Fournal of the Marine Biological Association of the United Kingdom, 87, 16431653.

Submitted 19 Fune 2007. Accepted 17 November 2007. 